\section{Nyttig om forskningsbasert kunnskap}

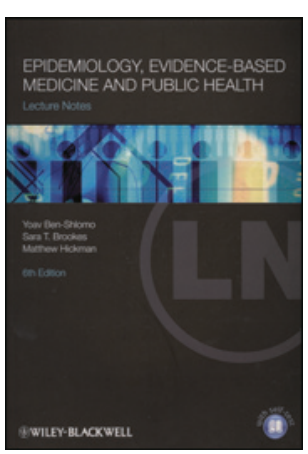

Yoav Ben-Shlomo, Sara Brookes,

Matthew Hickman

Epidemiology, evidence-based medicine and public health

Lecture notes. 6. utg. 238 s, tab, ill.

Chichester: Wiley-Blackwell, 2013.

Pris GBP 24

ISBN 978-1-4443-3478-4

Denne angivelig bestselgende læreboken er betydelig revidert i sin sjette utgave. Erfarne lærere ved universitetet i Bristol, England har satt seg ambisiøse mål ved å skulle gi medisinstudenter grunnleggende verktøy for å lære, praktisere og undervise epidemiologi, kunnskapsbasert medisin og samfunnsmedisin.

Boken, inndelt i de tre seksjonene epidemiologi, kunnskapsbasert medisin og samfunnsmedisin, er godt skrevet og utmerker seg ved en ryddig struktur, klart definerte læringsmål og nøkkelpoenger, selvtestspørsmål for hver del og gjennomgående gode illustrasjoner og klinisk relevante eksempler.

Epidemiologidelen introduserer grunnleggende prinsipper og vitenskapelige metoder for epidemiologiske studier på en pedagogisk måte. Et nytt kapittel om genetisk epidemiologi gir en god innføring i nye fremskritt og utfordringer relatert til klinisk nytte av genomprofilering. Innføringen i målemetoder og statistikk er velskrevet og inkluderer formler for utregning av blant annet konfidensintervaller, som nok kan være tungt tilgjengelig uten ledsagende undervisning.

Seksjonen om kunnskapsbasert medisin introduseres i denne utgaven gjennom forfatternes erkjennelse av at leger trenger å kunne applisere den best tilgjengelige forskningsbaserte kunnskapen i egen klinisk praksis. Kapitlene er skrevet i et klassisk klinisk epidemiologisk perspektiv med vekt på kritisk vurdering av studier innen diagnostikk, prognose og behandling. Her når ikke forfatterne sine mål om at leseren skal kunne praktisere kunnskapsbasert, da boken ikke gir oppdatert kunnskap om hvor og hvordan man søker etter den beste kunnskapen, identifiserer troverdige faglige retningslinjer og bruker dem i praksis og hvordan man inkluderer pasientens preferanser og verdier i kliniske beslutninger. Spesielt savnes omtale av nye standarder og systemer som GRADE, som i økende grad benyttes i troverdige systematiske oversikter og retningslinjer.

Delen om samfunnsmedisin er mindre klinisk rettet, men oppleves allikevel høyst relevant. Her gir forfatterne god innsikt $\mathrm{i}$ hvordan helsesystemer fungerer i forskjellige deler av verden og hvordan forskning på tiltak for å forbedre folkehelsen bør og kan gjennomføres. Kapitlet om screening bør gi leseren god forståelse av sentrale problemer også i et klinisk perspektiv.

Denne boken kan absolutt være nyttig for medisinstudenter og leger. Delen om kunnskapsbasert medisin bør suppleres av andre lærebøker eller nettressursen kunnskapsbasertpraksis.no. Medisinstudiene og spesialistutdanningen i Norge er for tiden under betydelig revisjon, og lærekreftene kan også ha nytte av å lese boken.

\section{Slagkraftig om vårt viktigste organ}

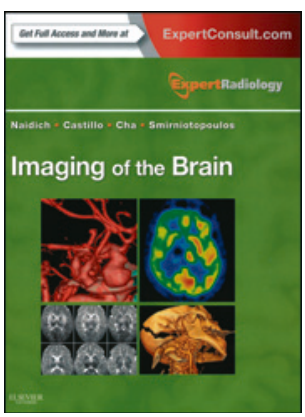

\author{
Thomas P. Naidich, Mauricio Castillo, \\ Soonmee Cha et al, red. \\ Imaging of the brain \\ Expert radiology series. 1052 s, tab, ill. \\ Philadelphia, PA: Elsevier Saunders, 2013. \\ Pris EUR 251
}

ISBN 978-1-4160-5009-4

Forfatterne er en gruppe forskere med usedvanlige kvalifikasjoner. Gjennom sin virksomhet og sitt intellekt har de inngående kjennskap til hjernens anatomi og nevroradiologiens muligheter. Disse to kunnskapsområdene har de fusjonert på en slik måte at maken til bok foreløpig ikke er utgitt. Som gammel nevroradiolog med erfaring fra tiden før CT og MR blir jeg atter engang overveldet over hvilken utrolig utvikling dette fagfeltet har gjennomgått de siste decennier.

Illustrasjoner og tabeller er av uvanlig god kvalitet, og systematikken gjør det lett å finne frem, hvilket gjør boken spesielt godt egnet som oppslagsverk. Det er i alt 50 kapitler fordelt på 13 seksjoner. Alle tenkelige nevrologiske sykdommer og nevrotraumer er representert med radiologiske bilder av usedvanlig god bildekvalitet, ofte med sidestilte patologiske preparater. Boken omhandler ikke nevroradiologiske intervensjonsteknikker, men viser en del eksempler på tilstander etter intervensjon.

Målgruppen er først og fremst radiologer som befatter seg med diagnostikk i sentralnervesystemet. Klinisk arbeidende nevrologer og nevrokirurger vil utvilsomt også ha nytte av å ha denne læreboken for hånden. Etter hvert er det en rekke spesialister innen psykiatri og psykologi som arbeider med MR-bilder og/eller behandler disse med tanke på å forstå hjernens funksjoner. For disse er boken nyttig, spesielt seksjonen om den normale hjernen, med inngående beskrivelse av gyri og sulci på hjernens overflate.

Det er lett å slutte seg til uttalelsen til Thomas Naidich: «We hope that this volume will help you to share the beauty and joy we find in neuroradiology.»

Per H. Nakstad

Oslo universitetssykehus

Per Olav Vandvik

Institutt for helse og samfunn

Universitetet i Oslo

Ola Saatvedt

Faculty of medicine

Jagiellonian University Krakow 